Research:

\title{
Small micro and medium entreprise empowerment strategy through stakeholder involvement to increase the performance
}

\author{
Sri Harini \\ Universitas Djuanda Bogor, Indonesia \\ sriharini@unida.ac.id \\ Erni Yuningsih \\ Universitas Djuanda Bogor, Indonesia \\ Susi Hambany \\ Universitas Djuanda Bogor, Indonesia
}

Received: July 25, 2019; Accepted: August 12, 2019; Published: December 31, 2019

To cite this article: Harini, Sri, Erni Yuningsih, Susi Hambany. 2019. Small Micro and Medium Entreprise Empowerment Strategy Through Stakeholder Involvement to Increase the Performance. The Management Journal of BINANIAGA. 4 (2): 33-44. doi: 10.33062/mjb.v4i2.334

\begin{abstract}
The purpose of the research is to identify and mapping of Micro Small and Medium Enterprises (MSMEs) condition in Bogor area, also to recommendation the policy and empowerment the policy of SMME through the stakeholder involvement, so it can be able to increase the MSMEs performance. The research's object is MSMEs in Bogor area. It uses the SWOT analysis with the desk study research method that is collecting data or seconder information that relevant to the research activity and approach method survey that is collecting the data or primer information with in-depth interview method and Focus Group Discussion (FGD), and the parties relating to this research. Finding this research is value of IFAS score of 2.90 and the value of EFAS score of 2.55 then obtained Matric Internal-External (IE Matric). Based on the above conditions where the relative IFAS score above average and EFAS score medium, then strategy that can be applied to that position is stability strategy or growth through horizontal integration.
\end{abstract}

Key-words: strategy, empowerment, and performance.

\section{Introduction}

MSMEs is one of Economic subject in Indonesian Economic. To develop MSMEs becomes a strong and independent enterprise, the various regulation is published by the government to make the founding direction clearly and successful. Small enterprise is a part of the world integral enterprise, which form of economics' people activity that has position, potential and strategic role to actualize the national Economic structure. The small enterprise needs to be useful in exploitation the enterprise's opportunity and to answer the Economic development challenge in the future. In 2008, government published the regulation No. 20, 2008 about Micro Small and Medium Enterprises (MSMEs) for growing and developing the MSMEs, to build the national Economic based on equitable Economic democracy.

The MSMEs development indicates the significant increases every year. It comes from the enterprise sector, labor absorption, gross domestic product contribution, export as well as the investment. MSMEs can be encouraged by some policies either from the government or the business peoples of MSMEs by strengthening human resources, and

Sri Harini, Erni Yuningsih, and Susi Hambany. Small Micro and Medium Entreprise Empowerment Strategy Through Stakeholder Involvement to Increase the Performance 
maximize the implementation of MSMEs policies (Maulida and Yunani, 2018). Meanwhile, the MSMEs founding evaluation can be done in accordance phase start with increasing ability of marketing management process, finance and personnel, then increasing ability of operational sector and business management. MSMEs is demanded to be able in accepting and adopting the technology and doing innovation on it.

Various strategies to empower MSMEs are enlarging access to credit, providing facilities, providing training, support on marketing and developing partnership with related sectors, (Antini, 2015). MSMEs development pattern batik with innovation renew the product then applying social capital by multiplying tissues business ecosystem, (Setyanto, Samodra, and Pratama, 2015). The size and purpose of the policy resources are factors that encourage and inhibit of MSMEs, (Dewindra and Astuti, 2018). The requiring to intervention of the local government, the effort of Cooperatives, SMEs, Trade and Industry, that can help foster economic activity and society. The effort to empowerment MSMEs must be done comprehensively and the stakeholder involvement is needed, (Harini, Sudarijati, and Arsyad, 2018). According to that, so development strategy is needed through the MSMEs empowerment which adequate to accommodate all the concerning involvement. It can increase the MSMEs performance, so the region economic development can increase too.

\section{Library Review}

\section{Implication of Micro Small and Medium Enterprises}

MSMEs is kind of enterprise which have a large amount in Indonesia, but the definition about this criteria is still in variation. The simple implication about small enterprise is relative; it needs definition to occur the implication in all sectors. Definition about small and medium enterprises from UU No. 20 Year 2008; Tambunan (2017) from several aspects is:

a. Based on the total asset

Small enterprise is the enterprise that has the neat asset maximum $200,000,000$ IDR (two hundred million rupiah), it does not include the land and building's place of business.

b. Based on the total sale point

Small enterprise is the enterprise that has the neat sale totals maximum $1,000,000,000$ IDR (one billion rupiah) per year.

c. Based on the ownership status

Small enterprise is the enterprise that belongs to individual form. It can be formed with legal corporation or not. Cooperation includes in it.

According to Statistics Corporation Center, the implication of MSMEs is kind of enterprise or industry with 5 until 15 employers. According to Finance Department, small enterprise is production enterprise belong to the family or individual's Indonesian citizen that has the selling asset maximum 1,000,000,000 IDR (one billion rupiah) per year. According to Cooperation and MSMEs minister, small enterprise is belong to Indonesian citizen, individual or legal corporation that has the neat asset maximum 200,000,000 IDR (two hundred million rupiah) and it has the selling output value or income maximum $1,000,000,000$ IDR (one billion rupiah), and it is independent.

From all the implications above, we can conclude that SMME is a company or industry within 5 until 15 employers that has selling asset 1,000,000,000 IDR (one billion rupiah) per year and it is independent.

\section{Characteristic of Micro Small and Medium Enterprises}

The characteristic of MSMEs in Indonesia is still variation and it is depend on the concept that used. Small enterprise is often identically with the entrepreneur that

Sri Harini, Erni Yuningsih, and Susi Hambany. Small Micro and Medium Entreprise Empowerment Strategy Through Stakeholder Involvement to Increase the Performance 
manages the low Economic group. So it makes many different opinions about the small enterprise's characteristic.

The MSMEs characteristics refer to the regulation No. 9, 1995 are:

a. It has the neat asset maximum 200,000,000 IDR (two hundred million rupiah). It does not include land and building's place of business.

b. It has the selling outcome maximum 1,000,000,000 IDR (one billion rupiah)

c. It is Indonesian citizen's property

d. It is independent. It is not the branch or subsidiary company, which is possessed, dominated or affiliated with the medium or large enterprise directly or indirectly.

The general characteristics of small enterprise are:

a. It has a simple organization's structure

b. It does not has the excessive staff

c. It does not has binding job's distribution

d. It has a short menagerie's structure

e. It has a few formal activity and it uses a planning process

f. It has less differentiation between personal asset and company asset

\section{Characteristic of Small Industry}

Category of the small industry's characteristics is:

a. Intensive Labor

Intensive labor characteristic makes the small industry can absorb many laborers especially the region laborer. So it can decrease the unemployment in the high growth inhabitants while there is a limit employment's condition. It makes the activities that can absorb the laborer, have an important role.

b. Small Asset

In major, small enterprise has a small capital relatively. The small capital's factor that has had by the small enterprise sector is because of the capital resource, which it comes from the personal fund. The second factor is, there are many requirements that must be fulfilled when they submit the application to the bank.

\section{c. Simple Technology}

Small enterprise usually uses the conventional technology. The used of conventional technology is because of the minimum's fund and the production need not the high technology.

\section{The Function and the Role of Micro Small and Medium Enterprises}

The function and the role of MSMEs has an extent effect in people Economic activities. It includes:
a. Commodity and service supplying
b. Laborer absorption
c. Income distribution
d. As an additional value for region's product
e. Increasingly of people's live level

Because it has a big role, so the founding and development of MSMEs not only important as the way to distribute all the development result, but also it is important as a main substance from all MSMEs structure in Indonesia. It is because the small investment can produce effectively and it can absorb many laborers.

\section{The Excess and Deficiency of Small Micro and Medium Enterprise (SMME)}

Some of the excesses from SMME to the large enterprise are:

a. Technology innovation is easy happened in developing product.

b. The intimate humanism relationship in small company.

c. It is able to create much employment opportunity or laborer absorption.

Sri Harini, Erni Yuningsih, and Susi Hambany. Small Micro and Medium Entreprise Empowerment Strategy Through Stakeholder Involvement to Increase the Performance 
d. It is flexible and able to adapt in market condition those changes faster, than the commonly bureaucratic large company.

e. There is managerial dynamism and entrepreneur's role.

Some barrier that causes weakness and obstacle to the MSMEs organizer is relate to the internal factor and MSMEs itself, also the external factor. The weakness of MSMEs is:

a. It does not has a long term planning

b. Lack of the business information

c. It does not has a proportional work distribution

d. Difficulty of working capital

e. Debt and risk to the third person is been responsible by the owner's wealth

f. The capital resource is limited to the capability of the owner

g. Planning and controlling of the program does not exist or it does not form yet.

\section{The Role of Government and A Competitiveness of MSMEs}

The role of government, entrepreneurship and business competence have a effect on the competitiveness of MSMEs, (Yuniarta, Diatmika, and Cipta, 2018). The role of the Regional Government, that strategy of empowerment and the development of MSMEs, (Habiburahman, Alam, and Dunan, 2019). MSMEs benefit from the program in terms of improved productivity, marketing and insights into MSMEs as an economic sector, (Kusumawardhani, Rahayu, Maksum, 2015). Government policies have effect on the performance of MSMEs, (Andreastika, Santoso, Deoranto, 2017). The various challenges, the MSME sector has shown admirable innovativeness, adaptability and resilience to survive the recent economic downturn and contribute significantly to India's industrial growth. The government iniciatives for enhancing the competitiveness of MSMEs (Chary \& Rao, 2016). The MSMEs can play a crucial role in employment, globalization, and can be very effective in the Global Value Chain (GVC) owing to their entrepreneurial and innovation driven growth, (Shrotriya, \& Dhir, 2018).

\section{Research Method}

The research's object is SMME in Bogor area (Bogor city and Bogor regency) including six sub districts. They are South Bogor, North Bogor, Center Bogor, West Bogor and Tanah Sareal which has 820,707 persons. Bogor city becomes a research's object appropriate to the vision: Trade city with the productive human resource and first-rate service. Bogor regency is divided into 40 sub districts that spread in North, East, Center, West and South Bogor area, with the wide of the area is 298,838,304 Ha. Bogor city and Bogor regency, with sum of the inhabitant and the location that near the capital city, is offer the opportunity to the positive Economic activity. The data are accumulating from primer and seconder data. The data's accumulation methods are: 1). Desk Study method is accumulating the data and seconder information. 2). Survey's Approach method is accumulating the data and primer information, use in-depth interview method to the Bogor city and regency's MSMEs cooperation offices, non-government organization, enterprise association, cooperation and educational institute. The information and the collected data are about the data and information that related to the policy and government program, it is about the MSMEs problem.

The interview is done and it is orientated to the interview orientation that will arrange. In this method, the information searches about respondent perception, development prospect, problem and defiance confronted the alternative strategic that suitable, also the direction and an expected form development of SMME's model. FGD (Focus Group Discussion) is done by orientated to arranged FGD's guideline. Between 8 for 10 people are invited to this FGD. They are some representative from the stakeholder that relate to the SMME. The respondent's criterion is the one who understand about

Sri Harini, Erni Yuningsih, and Susi Hambany. Small Micro and Medium Entreprise Empowerment Strategy Through Stakeholder Involvement to Increase the Performance 
various SMME's condition and situation in Bogor area. The respondent election's technique is quota and purposive sampling. The accumulated data's result, it can be primer or seconder, are processed and analyzed based on the kind of data and the purpose of data's usage. According to the method, this research uses the quantitative and qualitative analysis. Qualitative analysis is done by the document that comes from indepth interview and FGD (Focus Group Discussion). Quantitative analysis will be done to another data. Next, as a main input in research report arrangement, it will use the IFE and EFE analysis tools, also SWOT matrix.

\section{Result and Discussion}

MSMEs development strategy is determined by internal and external identification's factor. The chosen method in this research is to formulate the strategy. It uses the internal and external matrix factor. Both of that factors use the SWOT analysis. These analyses are comparing between internal strength and weakness factors to external opportunities and threat factors. These SWOT analysis factors are the result and research from the condition of common area and field observation, and after that the strategy is chosen by matrix analysis at quantitative strategy planning.

\section{Identification of Internal Factor}

Identification of Internal Factor is for identifying the factors that can be the strength and weakness to the SMME in Bogor. The Internal Factors are:

\section{Strength}

The strength factors that can be used in developing SMME in Bogor city are:

1. The Sum of SMME's quantity

Bogor city is one of the cities that have a lot of SMME. There are 3,200 SMME in Bogor, 700 units of it is founding of Trade and Industry Department. The sum of SMME in Bogor regency until 2013 is about 13,400. Every sub districts has excellent products such as bag, belt, convection, women shoes, bamboo's plait, dodol, cassava chips, tapioca, drying flower, etc. Many subject of SMME in Bogor city and Bogor regency are a special asset that can strengthen the Economic foundation in regional area and become a income source for the regional government.

\section{Government's endorsement through the law}

The regulation No. 20, 2008 about MSMEs is published as a base of law to empowerment the SMME and it is hoped to be escorted of MSMEs empowerment policy and make SMME be a strong and autonomous enterprise. With the assumption is that regulation can be implemented with the high commitment and consistent by the entire stakeholder, hence the MSMEs empowerment will produce the positive impact in ability of compete with the best performance. So it can survive and develop, to confront all the world Economic fluctuation. Afterwards, to develop MSMEs, the government's Bogor regency through the cooperation department, MSMEs, trading and industry decide the vision and mission. The vision are materialize of Bogor regency's cooperation, MSMEs, trading, industry and advanced service to increase theis compete with quality and quantity priority.

3. Increasing the region income

The MSMEs sector in Bogor city and Bogor regency gives a large contribution to the region's income. Many MSMEs that spreads in all areas give income to the government.

Sri Harini, Erni Yuningsih, and Susi Hambany. Small Micro and Medium Entreprise Empowerment Strategy Through Stakeholder Involvement to Increase the Performance 


\section{Intensive Labor}

Development of MSMEs in Bogor city and Bogor regency can absorb an employment in informal sector. Because of MSMEs does not absorb the high technology yet, so this sector can absorb many laborers as an intensive labor.

\section{Weakness} factors:

The weakness of MSMEs in Bogor city and Bogor regency is because of these

1. Market and Marketing aspect

The subject of MSMEs usually is family enterprise. It has the limitation in marketing access and has the weakness in negotiation and transaction. It causes the product is difficult to sell, even though the product is qualified.

2. Capital aspect

Capital is a main factor that needs to develop the enterprise unit. The less of MSMEs capital is because the small and medium enterprise is usually personal enterprise that relies on the limited capital from the limited person. It is hard to get the loan from the bank or finance, it is because the administrative and technical of the requirement is hard to complete.

3. Production aspect

The product of MSMEs usually does not has a quality standard, so there is no quality control. The product does not comply of the standard and there is no available in raw material guarantee.

4. Managerial capability

Most of small enterprise grows traditionally and as a family inheritance. The limited quality of human resource, skill, knowledge and formal education in small enterprise, are influence to the enterprise management. So that is why this enterprise is hard to develop optimally. Besides that, the limited of human resource quality can cause the enterprise hard to adopt the new development technology to increase the complete product.

5. Mentality

The problem of the entrepreneur is mentality which is easy to surrender, change the enterprise without doing the analysis or evaluation to the failure, than start from the zero again. The important thing that they often have forgotten in MSMEs problem is the entrepreneurship spirit. This spirit is meaning the willingness to keep innovation, diligent, hard to surrender, sacrificial and get a risk.

\section{External Identification Factor}

The result from external identification factor is opportunities and threat in Bogor city and Bogor regency's MSMEs. They are:

\section{Opportunities}

The opportunities factors that can be used in developing SMME in Bogor are:

1. Motivating the infestation development

Infestation is one of the motivations in Economic development. Infestations relates to the finance and Economic. It hopes the advantage in the future. SMME gives opportunities and motivate the infestation development in central and region.

Sri Harini, Erni Yuningsih, and Susi Hambany. Small Micro and Medium Entreprise Empowerment Strategy Through Stakeholder Involvement to Increase the Performance 
2. Increasing the region's competition

Entrepreneur or SMME's owner is a main activator in the company. Creativity, entrepreneurship, and innovation, are the main sources to increase the competition of SMME. Each region has excellent products that can be the characteristic of the region and it does not have in another region. This can be the opportunities to excavate the potential of the region. So it can be competed with another region. Bogor regency consist of 40 sub districts, each sub districts has each excellent product and as the central. For the example, the excellent product from Nanggung is ivory stone, wooden puppet, and farm's equipment and iron worker. The excellent product from Ciomas is shoes, Moslem's wear, food, beverage and haorta doll. The excellent product from Taman sari is shoes and handicraft. The central of Bogor regency's MSMEs are bag in Ciampea, sand in Tanjungsari, dodol in west Semplak, Kemang and Bojong Gede.

3. Labor absorption

MSMEs is one of the strategic sector in national Economic. It is seen from the high absorption of laborer by the MSMEs sector. The large amount of MSMEs in Bogor city and Bogor regency can absorb the labor. It cannot absorb in formal sector. According to the Cooperation department and MSMEs in Bogor city's data in 2014 , all of MSMEs in Bogor city that absorb in six sub districts get $1.9 \%$ enterprise unit's decrease, but it gets $4.8 \%$ in labor's absorption. It is because labor additional in several enterprise unit. This illustration shows the development's opportunities of MSMEs that can absorb labor in non-formal sector. This group has a large potential. It can solve the unemployment and poverty problems.

\section{Creative Economic Development}

In Indonesia, MSMEs is used as an instrument of social policy or the policy to decrease unemployment and poverty. In order that SMME can move and develop, it must have creativity and innovation from the entrepreneur. It is not because of the force to live from all the program, credit or government special helping.

\section{Threat}

The threat's factors that can influence to develop tourism sector are:

1. Asian Economic Community (AEC)

An available of domestic and global market becomes a threat to MSMEs development. It is also because of the unsteady Indonesian Economic fundamental background. It forces the government to develop Economic structure that considering the existence of MSMEs. One of negative effect that appear in MEA is there are so many products will come inside the domestic. It makes the tight competition.

2. The unconducive enterprise's climate

The enterprise climate is a government's effort condition to empower the MSMEs synergy through the decision of MSMEs regulation and the policy in all economic aspect. The small micro and medium enterprise must get partiality, assurance, opportunities, protection and support to the large enterprise. The government policy, to develop the MSMEs, even it always completes every year, is not conducive yet. It is seen by the unhealthy competition between the small and medium with the large entrepreneur. Another barrier that is faced by the SME is barrier of getting the license to operate their enterprise. Some of complaining is often heard. It is about many procedures that must follow through the expensive cost, in a long term. It related to the government's Economic policy. It does not take side to the MSMEs but more interest to the large entrepreneur.

Sri Harini, Erni Yuningsih, and Susi Hambany. Small Micro and Medium Entreprise Empowerment Strategy Through Stakeholder Involvement to Increase the Performance 


\section{Economic}

Economic factor supposed to be influence to MSMEs development. It includes: regional Economic trend, people's income degree, people's purchase degree, regional standard of minimum wages degree, interest rate degree, and rupiah's exchange rate degree. Unconducive Economic makes a bad influence to the stuff's selling and decrease the selling.

4. Politic

Condition and politic factor influence the MSMEs because it relate to the policy or the government role to develop MSMEs.

5. Technology

Beside the funding access, MSMEs also gets difficulty to information access. The minimum information that is known by the MSMEs, influence to the product or service competition from the quality of MSMEs product with another. This causes the MSMEs product and service cannot break the export market. In another side, there are some product and service that potential to fight in international market, but just because there is not access, at the end it just circulate in domestic market.

\section{Determine the strategy and the policy.}

In developing MSMEs, it needs the strategy to defend and develop the directness of MSMEs in the future. Generally, the strategy has some components. It is considered to decide the strategy that will do. In arrange the strategy, one of activity that must do is internal and external situation analysis. This analysis needs to analyze the strength and weakness, also opportunities and threat. One of approach to analyze this situation is SWOT analysis, abbreviation from Strength, Weakness, Opportunities and Threat.

\section{SWOT Analysis}

For helping to formulate the next planning, it is used the SWOT analysis instruments. SWOT analysis is a systematic way to identifying the internal and external factors. It is the strategic form that illustrates the best appropriateness. This analysis based on the assumption that the strategy will make the strength and opportunities maximum and it appears the weakness and threat. This is the result of SWOT analysis:

Table. Strength, Weakness, Opportunities and Threat of MSMEs Bogor.

\begin{tabular}{|c|l|c|c|c|c|}
\hline No & Internal and External Factor Strategy & Strength & Weakness & Opportunities & Threat \\
\hline 1 & The sum of MSMEs quantity & $\sqrt{ }$ & & & \\
\hline 2 & Government's endorsement through the law & $\sqrt{ }$ & & & \\
\hline 3 & Increasing the region income & $\sqrt{ }$ & & & \\
\hline 4 & Intensive labor & $\sqrt{ }$ & & & \\
\hline 5 & Market and marketing aspect & & $\sqrt{ }$ & & \\
\hline 6 & Capital aspect & & $\sqrt{ }$ & & \\
\hline 7 & Production aspect & & $\sqrt{ }$ & & \\
\hline 8 & Managerial capability & & $\sqrt{ }$ & \\
\hline 9 & Mentality & & & $\sqrt{ }$ & \\
\hline 10 & Motivating the investment development & & & $\sqrt{ }$ & \\
\hline 11 & Increasing the region's competition & & & $\sqrt{ }$ & \\
\hline 12 & Labor absorption & & & & $\sqrt{ }$ \\
\hline 13 & Creative Economic development & & & & $\sqrt{ }$ \\
\hline 14 & Asian Economic Community (MEA) & & & & $\sqrt{ }$ \\
\hline 15 & The unconducive enterprise's climate & & & & $\sqrt{ }$ \\
\hline 16 & Economic & & & & \\
\hline 17 & Politics & & & & \\
\hline 18 & Technology and information & & & & \\
\hline
\end{tabular}

Sri Harini, Erni Yuningsih, and Susi Hambany. Small Micro and Medium Entreprise Empowerment Strategy Through Stakeholder Involvement to Increase the Performance 
After the conditions above known, it can determine the approach position use the SWOT analysis. With determine the internal factor approach strategic (IFAS) to determine the strength and weakness the training program. External factor approach strategic (EFAS) to determine the opportunities and threat in this program. The next step is to determine the score spread which use marking and rating, after that put the score into matrix so the position will know, than determine the strategy that must be applied.

Table. External Factor Analysis Summary (EFAS)

\begin{tabular}{|l|c|c|c|l|}
\hline \multicolumn{1}{|c|}{ External Factor Strategic } & Value & Rating & Score & \multicolumn{1}{|c|}{ Note } \\
\hline 1. Opportunities & 0.5 & & & \\
\hline $\begin{array}{l}\text { Motivating the investment } \\
\text { development }\end{array}$ & 0.15 & 4 & 0.6 & It has pushed the investment \\
\hline Increasing the region's competition & 0.15 & 4 & 0.6 & $\begin{array}{l}\text { It has increased the region's } \\
\text { competition }\end{array}$ \\
\hline Labor absorption & 0.10 & 4 & 0.4 & MSMEs can absorb the labor \\
\hline Creative Economic development & 0.10 & 3 & 0.30 & $\begin{array}{l}\text { MSMEs can increase the } \\
\text { creative Economic } \\
\text { development }\end{array}$ \\
\hline 2. Threat & & & & \\
\hline Asian Economic People (MEA) & 0.10 & 1 & 0.10 & Needs to be carefully \\
\hline The unconducive enterprise's climate & 0.15 & 1 & 0.15 & Needs to be interested \\
\hline Economic & 0.15 & 2 & 0.30 & Be careful \\
\hline Politic & 0.05 & 1 & 0.05 & \\
\hline Technology and information & 0.05 & 1 & 0.05 & Needs to be interested \\
\hline Sum & 0.5 & & 2.55 & \\
\hline
\end{tabular}

Interpretations: According to EFAS matrix above, it gets score 2.55

Information about rating for opportunities and threat

4 value: the largest opportunities, 3 value: large opportunities, 2 value: large threat, 1 value: the largest threat

\section{Total of Internal Factor's Score}

\begin{tabular}{|c|c|c|c|c|}
\hline & & 4.0 Strong & 2.0 Weak & 1.0 \\
\hline \multicolumn{2}{|l|}{ High } & $\begin{array}{l}\text { Development } \\
\text { through the vertical } \\
\text { integration }\end{array}$ & $\begin{array}{l}\text { Development throug } \\
\text { the horizontal } \\
\text { integration }\end{array}$ & Through turn around \\
\hline \multirow{3}{*}{$\begin{array}{l}\text { Score total } \\
\text { External } \\
\text { Factor }\end{array}$} & 3.0 & Stability & Development through & Devastation \\
\hline & Medium & & $\begin{array}{l}\text { the horizontal stability } \\
\text { (It does not change of } \\
\text { strategy profit) }\end{array}$ & \\
\hline & $\begin{array}{l}2.0 \\
\text { Low }\end{array}$ & $\begin{array}{l}\text { Development } \\
\text { through the } \\
\text { concentric } \\
\text { diversification }\end{array}$ & $\begin{array}{l}\text { Development through } \\
\text { the conglomerate } \\
\text { diversification }\end{array}$ & Liquidation \\
\hline
\end{tabular}

Figure. Internal and External Matrix

After knowing the value of IFAS score of 2.90 and the value of EFAS score of 2.55 then obtained Matric Internal-External (IE Matric). Based on the above conditions where the relative IFAS score above average and EFAS score medium, then strategy that can be applied to that position is stability strategy or growth through horizontal integration.

Sri Harini, Erni Yuningsih, and Susi Hambany. Small Micro and Medium Entreprise Empowerment Strategy Through Stakeholder Involvement to Increase the Performance 
Based on all the analysis above, alternative SMME strategy based on SWOT analysis can be arranged as follows:

1. Increased institutional empowerment of the MSMEs in other to increased investment areas and competitiveness.

2. Increased the founding of the MSMEs gradually through identification, the potential mapping area by stakeholder's involvement.

3. Weaves in intensive and comprehensive with stakeholders ranging from educational institutions, financial institutions, cooperatives, business association and NGOs (NonGovernment organization).

4. Increased access MSMEs against funding sources.

5. The development of the market network and marketing to improve competitiveness.

6. Empowerment in the field of production through the help of selective business sectors and a stimulant.

7. Empowerment resource quality MSMEs

8. Create medium-sized small medium business climate conducive through facilitation policy.

9. Increased entrepreneurship program in improving the competitive advantage SMME.

10. Improved information technology.

Based on the conclusion while retrieved the results as follows:

1. The identification of the internal factors that could be the strengths and weaknesses facing MSMEs in Bogor is include the power factor: a large number of SMME, government support through the legality, increasing the original income area, solid works, and weakness factors: aspects of the market and marketing, capital aspects, production, managerial ability, and mentality aspect.

2. Identification internal factors that can be strengths and weaknesses facing MSMEs in Bogor is include opportunities and threats. Opportunities factors are: factors promote the development of investment, increasing the regional competitiveness, absorbing labor, creative economic, development as well as threats factors include: Asian Economic Community (MEA), business climate has not been fully conducive, economic, political enhancement, technology and information

3. Based on SWOT analysis compiled strategies include: improved institutional empowerment MSMEs, an increase coaching MSMEs gradually through identification, the potential mapping area by engaging stakeholders, establish an intensive and comprehensive with the stakeholders ranging from educational institution, financial institution, cooperatives, business associations and nongovernmental organizations (LSM), an increase MSMEs access to the funding sources. The development of the market network and marketing to improve competitiveness of empowerment in the field of production through the help of selective business sectors and stimulant, SMME resources quality empowerment, creating a climate medium-sized small business that are conducive through facilitation policy, increased entrepreneurship program in improving the competitive advantage MSMEs, an increase of information technology.

\section{References}

Andreastika, K., Santoso, I., and Deoranto, P. (2017) Competitiveness Of Food AgroIndustrial MSMEs: Role Of Business Management And Government Policy, Jurnal Aplikasi Manajemen, 15(3), 501-512.

Antini, T. (2015) Strategi Pemerintah Daerah Dalam Pemberdayaan Usaha Mikro Kecil Menengah (UMKM) Berbasis Potensi Lokal (Studi Terhadap Pemberdayaan Umkm Batik Di Kabupaten Banyuwangi), Jurnal Administrasi Publik, 3(10), 1626-1631.

Sri Harini, Erni Yuningsih, and Susi Hambany. Small Micro and Medium Entreprise Empowerment Strategy Through Stakeholder Involvement to Increase the Performance 
Chary, D. T., and Rao, R. S. (2016) Challenges of MSMEs in India - Government Initiatives for Enhancing Competitiveness of MSMEs in India, 5th Annual International Research Conference- 2016 Faculty of Management and CommerceSEUSL, 143-153.

Dewindra, R. D., Astuti, R. S. (2018) Implementasi Peraturan Daerah Kota Semarang Nomor 13 Tahun 2013 Tentang Pemberdayaan UMKM di Kecamatan Gunung Pati, Journal of Public Policy and Management Review, 7(4), 1-12. DOI: 10.14710/jppmr.v7i4.21971.

Habiburahman, Alam, I. A., and Dunan, H. (2019) MSMEs Empowerment and Development Strategy Model, Review of Integrative Business and Economics Research, 8(2), 324-332.

Harini, S., Sudarijati, Arsyad, A. (2018) Analysis of the Effects Of Government Policy and the Involvement of Stakeholders on the Performance of MSMEs, Matrik : Jurnal Manajemen, Strategi Bisnis dan Kewirausahaan 12(1), 15-24.

Kusumawardhani, D., Rahayu, A. Y., Maksum, I. R. (2015) The Role of Government in MSMEs:The Empowerment of MSMEs During the Free Trade Era in Indonesia, Australasian Accounting, Business and Finance Journal, 9(2), 23-42.

Maulida, S., Yunani, A. (2018) Peluang dan Tantangan Pengembangan Usaha Mikro Kecil Menengah (UMKM) dari Berbagai Aspek Ekonomi, Jurnal Ilmiah Manajemen \& Bisnis, 2 (1), 181-197.

Putri, K.A.D., (2015) Pemberdayaan Usaha Mikro, Kecil, Dan Menengah (UMKM) Berbasis Agroindustri (Studi pada Dinas Koperasi, UKM, Perindustrian dan Perdagangan Kota Batu), Jurnal Administrasi Publik, 3(2), 243-251.

Setyanto, A. R., Samodra, B. R., Pratama, Y. P. (2015) Kajian Strategi Pemberdayaan UMKM Dalam Menghadapi Perdagangan Bebas Kawasan ASEAN (Studi Kasus Kampung Batik Laweyan), ETIKONOMI, 14(2). DOI: 10.15408/etk.v14i2.2271.

Shrotriya, S., \& Dhir, S. (2018). MSME Competitiveness for the Global Value Chain-A TRIZ-Based Approach. In Global Value Chains, Flexibility and Sustainability (pp. 33-46). Springer, Singapore.

Tambunan, T.T.H. (2017) Usaha Mikro kecil dan Menengah, Jakarta: Galia Indonesia.

Yuniarta, G. A., Diatmika, I P.G., and Cipta, W. (2018) The Role of Government, Entrepreneurship, and Business Competence In Order To Improve The Competitiveness of Micro, Small, and Medium Enterprises (MSMEs), Advances in Economics, Business and Management Research, 69, 281-285.

Sri Harini, Erni Yuningsih, and Susi Hambany. Small Micro and Medium Entreprise Empowerment Strategy Through Stakeholder Involvement to Increase the Performance 
The Management Journal of BINANIAGA Vol. 04, No. 02, December 2019 p-ISSN: $2527-4317$, e-ISSN: $2580-149 x$

$6^{\text {th }}$ Accreditation Rating: April 04, 2019-April 03, 2024

This page intentionally be emptied.

Sri Harini, Erni Yuningsih, and Susi Hambany. Small Micro and Medium Entreprise Empowerment Strategy Through Stakeholder Involvement to Increase the Performance 